\title{
Prevalence, distribution and control of six major potato viruses in Kenya
}

\author{
John Onditi ${ }^{1,2} \cdot$ Moses Nyongesa $^{2} \cdot$ René van der Vlugt $^{1}$ (i) \\ Received: 15 June 2020 / Accepted: 12 November 2020 / Published online: 7 December 2020 \\ (C) The Author(s) 2020
}

\begin{abstract}
In most developing countries, farmers lack sufficient supply of certified or healthy potato seed tubers. Hence, they often plant their own saved ware potato tubers, a practice that is known to contribute to spread and increase the prevalence of plant viruses. In this study, we proposed options for managing the virus based on the knowledge obtained from surveys of virus prevalence and distribution in potato cultivars grown under such conditions. Potato leaf samples randomly collected from 354 farms in five major potato-growing counties in Kenya were tested for six potato viruses; potato virus Y (PVY), potato leaf roll virus (PLRV), potato virus $\mathrm{X}$ (PVX), potato virus $\mathrm{M}$ (PVM), potato virus A (PVA) and potato virus S (PVS) through DAS-ELISA. Virus prevalence in the fields was high; $72.9 \%$ of the samples were positive for at least one of the six viruses; and 55.9\% showed multiple infections. A follow-up survey conducted during three consecutive seasons, in two of the five counties, revealed that virus prevalence fluctuated across seasons. This suggested that updated information on virus prevalence might be of value for designing a virus control strategy. Distribution maps showed the presence of the viruses restricted to specific geographic regions, an indication of where control efforts should be directed. Four cultivars, Sherekea, Shangi, Kenya Karibu and Asante, grown at a high virusprevalent area, showed low values of average ELISA absorbance (OD), suggest a field resistance to the viruses. This study demonstrated that knowledge of prevalence and distribution may be of value to identify and recommend virus resistant cultivars to replace susceptible ones, especially in the virus hotspot areas.
\end{abstract}

Keywords Potato $($ Solanum tuberosum) $\cdot$ Virus $\cdot$ Prevalence $\cdot$ Distribution $\cdot$ Kenya

\section{Introduction}

Potato (Solanum tuberosum L.) is globally ranked as the fourth most important food crop after wheat, rice and maize. The crop is distributed worldwide in over 100 countries and is considered an important crop in all continents (Birch et al. 2012). Over the past five decades, the crop has increased its importance in East and Central Africa (Scott et al. 2013). In Kenya, potato is the second most important food crop after maize and plays an important role in ensuring food security of the country (MoALF 2016). Despite its importance, average

René van der Vlugt rene.vandervlugt@wur.nl

1 Laboratory of Virology, Wageningen University and Research, Wageningen, The Netherlands

2 Kenya Agricultural and Livestock Research Organization (KALRO), Horticultural Research Institute, Potato Research Centre, Tigoni, P.O. Box 338, Limuru 00217, Kenya potato yield in the farmer's fields is low (8.7 T/ha) as compared to the leading potato producers in the world which produce between 40 to $60 \mathrm{~T} / \mathrm{ha}$ (FAOSTAT 2017) under wellestablished seed systems, pest and disease surveillance and effective virus control (Whitworth and Davidson 2008; Wang et al. 2011). High incidence of pests and diseases are a big challenge in potato production, causing low profitability and consequently threatening food security (Thomas-Sharma et al. 2016).

Viruses are also among the most important vector and seed-borne diseases of the potato crop (Salazar 1996). Out of over 40 viruses which can infect potato (Whitfield et al. 2015), the six best known viruses: potato virus Y (PVY, genus Potyvirus), potato leaf roll virus (PLRV, Polerovirus), potato virus X (PVX, Potexvirus), potato virus A (PVA, Potyvirus), potato virus S (PVS, Carlavirus) and potato virus M (PVM, Carlavirus) have been reported to be most important in Kenya (Were et al. 2003; Muthomi et al. 2009; Were et al. 2013) and even in the neighbouring countries Ethiopia, Uganda and Tanzania (Gildemacher et al. 2011; Priegnitz et al. 2019). 
PVY, PLRV and PVX have attracted more attention than PVM, PVS and PVA due to high losses they cause on yield (Taliansky et al. 2003) generally associated with more symptoms. In the farmer's fields, multiple infections commonly occur with an increased synergistic effect on the crop, subsequently leading to higher yield losses (Brandolini et al. 1992; Kerlan and Moury 2008). In susceptible potato cultivars, the viruses cause general poor vegetative growth and loss in tuber yield, coupled with symptoms such as leaf roll, mosaic, leaf drop, chlorosis, stunted growth and necrosis and production of undersized tubers and sometimes death of the whole plant (Jayashige et al. 1989; Beukema and van der Zaag 1990).

In addition to being tuber-borne, all six potato viruses are transmitted by various aphid species except PVX which is transmitted through contact (Whitfield et al. 2015) and PVS, which can also have aphid-transmitted strains (Kreuze et al. 2020). Some of the aphid species that transmit potato viruses have been found to occur with high incidence in potatogrowing regions in Kenya (Olubayo et al. 2010; Muthomi et al. 2009; Were et al. 2013). Existence of alternative weed host plants of the viruses in or around potato fields is among the factors that contribute to further spread of the viruses (Were et al. 2003; Nyamwamu et al. 2014; Smith et al. 2012). Among the seed producers, viruses lower the quality standards of the various classes of seed potato, and in cases where virus prevalence exceeds legal limits of the phytosanitary authorities, the seed lot is normally rejected and seed producer's loose profitability (Kaguongo et al. 2014; Soliman et al. 2012; Kim and Kwon 2019). In Kenya, certified seed tubers are scarce ( $<5 \%$ of seed tubers planted), a fact that may be contributing to high virus prevalence in the farmer's fields (NPCK 2017). Planting such low quality seed tubers leads to transmission and accumulation of viruses over subsequent seasons of replanting virus-infected tubers (Onditi et al. 2013). High prevalence and rapid spread of potato viruses normally occur in cases where effective measures are not put in place for virus control (Frost et al. 2013; Yadav and Khurana 2015). Knowledge of prevalence, geographical distribution and relative economic impact of the different potato viruses can be essential in implementation of control strategies (Tesfaye et al. 2011). This study was therefore conducted to (a) describe prevalence and spatial distribution of the six major viruses and (b) make inferences about virus resistance in particular cultivars from virus prevalence surveys and (c) suggest cultivars, regions and viruses that should be given priorities in potato virus control in Kenya.

\section{Materials and methods}

A survey was conducted in farmer's fields in the five major potato-growing regions in Kenya administratively demarcated as Bomet, Nakuru, Kiambu, Nyandarua and in Meru counties (see Figs. 3, 4, 5, 6, 7 and 8). In these regions, there are two main potato-growing seasons in a year; the short rains (October-December) and long rains (April-July).

Potato leaf samples were collected from a total of 354 farms (80 in Bomet, 65 in Nakuru, 64 in Kiambu, 65 in Nyandarua and 80 in Meru) during the main potato-growing season of 2016 (long rains 2016). Four samples (tested as one composite) were taken randomly from within each farm without bias on symptomatic or asymptomatic plants. Leaf samples were collected from the third leaf from the top of the plant and at a time when the potatoes were at early vegetative stage towards flowering (30 to 60 days after planting). Simple random sampling was used to identify survey sites. The survey sites were randomised using the QGIS software (QGIS 2019) according to the total number of samples for each of the five counties. Potato farms which fell on or closest to the QGISgenerated GPS coordinates were identified for the survey. To compare virus prevalence over the consecutive seasons, sampling continued in two of the five potato-growing regions (Nyandarua and Meru) during the short rains 2016 and long rains 2017 with the same number of samples from the same field per region every season.

Data were collected on the cultivar sampled and the geographic positioning systems (GPS) coordinates (longitudes and latitudes) of the farms using the UTM geo map android application. Actual GPS coordinates of the farms where samples were collected were used to generate distribution maps using QGIS software (QGIS Development Team 2019) to visualise the virus distribution patterns. Leaf samples were collected in the field in plastic bags which were transported in ice cold styrofoam boxes to the research station where they were stored at $4{ }^{\circ} \mathrm{C}$ and analysed within 3 days after collection by DAS-Enzyme Linked Immuno-Sorbent Assay (Double Antibody Sandwich ELISA) (Clark and Adams 1977). The antibodies for the potato six viruses (PVY, PLRV, PVX, PVM, PVA and PVS), the kit and instructions for ELISA detection were obtained from the International Potato Centre (CIP), Lima, Peru. The samples were tested at Kenya Agricultural and Livestock Research Organization (KALRO), Potato Research Centre, Tigoni, Kenya. ELISA coating solution was prepared by diluting the coating antibody for each of the six viruses (PVY, PLRV, PVX, PVM, PVS and PVA). Coating solution consisted of $35 \mu \mathrm{l}$ of the antibodies (IgG) in $10 \mathrm{ml}$ of coating buffer $\left(0.2 \mathrm{~g} \mathrm{Na}_{2} \mathrm{CO}_{3}, 0.44 \mathrm{~g}\right.$ $\mathrm{NaHCO} 3,0.03 \mathrm{~g} \mathrm{NaN} 3 \mathrm{pH} 9.6$ in $120 \mathrm{ml}$ of distilled water).

Wells of the ELISA plates (Thermo Scientific, Denmark) were loaded with $100 \mu$ l of the coating solution and incubated overnight at $4{ }^{\circ} \mathrm{C}$. The plates were washed 3 times with a 3min rinse between the washes. The washing buffer consisted of $8.0 \mathrm{~g} \mathrm{NaCl}, 0.2 \mathrm{~g} \mathrm{KH}_{2} \mathrm{PO}_{4}, 0.2 \mathrm{~g} \mathrm{KCL}, 1.13 \mathrm{~g} \mathrm{NaH}_{2} \mathrm{PO}_{4}$, $0.29 \mathrm{NaN}_{2}$ and $0.05 \%$ of Tween 20 in 11 of distilled water, $\mathrm{pH} 7.4$ (PBS-T). Leaf samples were macerated in 1:2 w/v ratio 
with ELISA extraction buffer $(0.2 \%$ egg ovalbumin, $2 \%$ PVP40, 0.05\% Tween-20 and 0.05\% NaN3 in 0.01 M PBS). Samples $(100 \mu \mathrm{l})$ were loaded in duplicates (side by side) in the ELISA plate including three positive and six negative controls and incubated overnight at $4{ }^{\circ} \mathrm{C}$. Because of the large number of samples collected tested for each virus (354), sample loading was conducted on multiple ELISA plates but following the same procedure. Buffer solutions were prepared and stored using the same protocol for all the samples. The same positive and negative controls were used for each test plate. The ELISA OD values of the controls from the different plates were comparable: within three times the standard deviation of their value. This low variation on the control OD values among microplates, allowed a comparison of results obtained from the different ELISA plates. Positive controls were potato leaf samples previously tested in ELISA and found infected with each of the six viruses respectively, and a negative control was a potato leaf sample confirmed to be without infection of any of the six viruses and stored at $20^{\circ} \mathrm{C}$. Positive and negative controls were of the same physiological age at the time of sample collection. After three plate washings, alkaline phosphatase (IgG-AP) conjugate antibody (1000 times diluted in extraction buffer) of each of the respective six viruses was added $(100 \mu \mathrm{l})$ and incubated overnight at $4{ }^{\circ} \mathrm{C}$. Colour development was done by adding $100 \mu \mathrm{l}$ of substrate solution $[0.75 \mathrm{mg} / \mathrm{ml}$ of paranitrophenylphosphate (pNPP) in substrate buffer (97 $\mathrm{ml}$ of diethanolamine, $\mathrm{pH} 9.8$ in $1000 \mathrm{ml}$ of distilled water)] and incubating at room temperature for $60 \mathrm{~min}$. An ELISA reader (Biotek 88TS, Vermont, USA) was then used to take optical density (OD) reading at a wavelength of $405 \mathrm{~nm}$. ELISA positive samples were calculated as those with values equal or greater than the mean of the negative controls plus three times the standard deviation.

Potato virus prevalence was calculated as the proportion of samples that tested positive for the viruses against the total number of samples tested. Analysis of variance (ANOVA) was on ELISA OD values and a least significant difference (LSD) of 5\% was used to compare means using the R statistical package. This was also used to summarise the differences in means of cultivars, regions and viruses and to make decision on the relative importance of the viruses.

\section{Results}

\section{Prevalence of the six viruses}

The virus prevalence's in five major potato-growing counties (Nyandarua, Kiambu, Nakuru, Meru and Bomet) as based on 354 potato leaf samples analysed in an ELISA assay for six viruses are summarised in Fig. 1. Virus infections were found in $72.9 \%$ of all the samples analysed, while the rest $(27.1 \%)$ tested negative for all the six viruses. Each of the six viruses was detected in all the counties with the exception of Nakuru where PVY was not detected. The virus prevalence varied from within one county to another. In the total of all the samples analysed, PVX was the most prevalent virus $(54.8 \%)$ followed by PVS (47.5\%) and PVM (13.0\%). PVY (8.2\%), PLRV (6.8\%) and PVA (2.5\%) occurred at lower prevalence.

Within each of the five counties, PVX and PVS were still the most prevalent while the rest of the viruses occurred at lower prevalences. In Nyandarua County, there was $86.2 \%$ PVS, 66.2\% PVX, 6.2\% PVM, 3.1\% PVY, 1.5\% PLRV and $1.5 \%$ PVA. In Nakuru County, PVX (67.9\%) and PVS $(52.3 \%)$ were still the most prevalent viruses followed by PVM (18.5\%), PLRV (1.5\%) and PVA (1.5\%) while PVY was not detected. Virus prevalence in the other three counties were as follows: $83.8 \%$ PVX, $35.0 \%$ PVS, $18.8 \%$ PVY, $11.3 \%$ PLRV, 5.0\% PVM and 2.5\% PVA in Meru County, 50.8\% PVS, 38.5\% PVX, 29.2\% PVM, 7.7\% PVY, $3.1 \%$ PVA and $1.5 \%$ PLRV in Kiambu County and $83.8 \%$ PVX, 35.0\% PVS, 18.8\% PVY, 11.3\% PLRV, 5.0\% PVM and $2.5 \%$ PVA in Bomet County.

\section{Occurrence of multiple infections}

The different combinations of infections of six viruses that occurred in the 354 samples from the five potato-growing counties are presented in Table 1. Three categories of the samples analysed were found, namely: multiple infections, single infection and those samples which were negative for all the six viruses (Table 1). Multiple infections occurred in 24 different combinations of the six viruses in $55.9 \%$ of the samples. The most common type of multiple infection was that involving a mixture of PVX and PVS which occurred in $23.4 \%$ of the samples. Other types of multiple infections included a mixture of PVX, PVM and PVS (6.2\%), PVM and PVS (2.5\%), PVY and PVS (1.1\%), PLRV and PVX (1.1\%) while the rest occurred at lower prevalence of less than $1.0 \%$. Single infections were found in $27.7 \%$ of the samples and only for PVX (19.8\%) and PVS (9.0\%). None of the six viruses was detected in $27.1 \%$ of the samples analysed.

\section{Potato virus prevalence across the consecutive seasons}

Prevalence of the six viruses were analysed for three consecutive seasons in two (Meru and Nyandarua) of the five counties. Potato leaf samples (65 in Nyandarua and 80 in Meru) were collected in the same farms during the long rains 2016, short rains 2016 and long rains 2017 (Fig. 2). Virus prevalence was found to be changing over time especially with PVX and PVS which was found to occur with the highest overall prevalence. There was an overall decreasing trend in PVX prevalence from 37.7 to 28.1 to $22.8 \%$ over the three seasons. Even though PLRV prevalence was relatively lower 
Fig. 1 Prevalence in percentages of potato virus $\mathrm{Y}$ (PVY) potato leaf roll virus (PLRV), potato virus $\mathrm{X}$ (PVX), potato virus $\mathrm{M}$ (PVM), potato virus A (PVA) and potato virus $\mathrm{S}$ (PVS) within each of the five major potato-growing areas in Kenya as based on DASELISA assays on a total of 354 potato leaf samples randomly collected from these regions

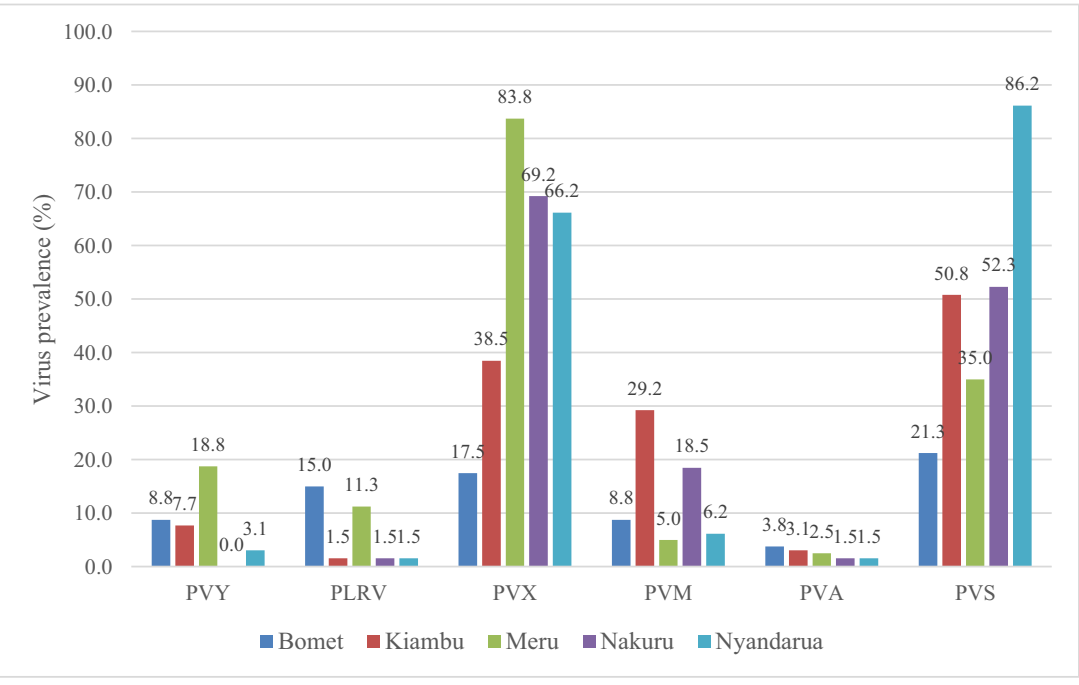

than that of PVX, there was still a decreasing trend from 3.4 to 3.1 to $2.8 \%$. In contrast, there was an increase in PVS prevalence from 29.0 to 33.1 to $36.9 \%$ over the seasons. Though with a lower prevalence than that of PVX, there was an increase in PVY from 4.1 to 4.7 to $7.2 \%$ over the seasons. PVA and PVM occurred at lower prevalence than the rest of the
Table 1 Prevalence of potato virus Y (PVY), potato leaf roll virus (PLRV), potato virus $\mathrm{X}$ (PVX), potato virus $\mathrm{M}$ (PVM), potato virus $\mathrm{A}$ (PVA) and potato virus $\mathrm{S}$ (PVS) in single and multiple infections in the total of 354 potato leaf samples collected from five major potato-growing regions in Kenya

\begin{tabular}{|c|c|c|}
\hline Type of multiple infection & No. of samples & Virus prevalence $(\%)$ \\
\hline No virus detected & 96 & 27.1 \\
\hline $\mathrm{PVX}+\mathrm{PVS}$ & 83 & 23.4 \\
\hline PVX & 70 & 19.8 \\
\hline PVS & 32 & 9.0 \\
\hline $\mathrm{PVX}+\mathrm{PVM}+\mathrm{PVS}$ & 22 & 6.2 \\
\hline $\mathrm{PVM}+\mathrm{PVS}$ & 9 & 2.5 \\
\hline $\mathrm{PVY}+\mathrm{PVS}$ & 4 & 1.1 \\
\hline PLRV+PVX & 4 & 1.1 \\
\hline $\mathrm{PVY}+\mathrm{PVX}+\mathrm{PVS}$ & 3 & 0.8 \\
\hline $\mathrm{PVY}+\mathrm{PLRV}+\mathrm{PVX}$ & 3 & 0.8 \\
\hline PVY + PLRV & 3 & 0.8 \\
\hline $\mathrm{PVY}+\mathrm{PLRV}+\mathrm{PVX}+\mathrm{PVM}$ & 2 & 0.6 \\
\hline PVY + PLRV+PVS & 2 & 0.6 \\
\hline $\mathrm{PVY}+\mathrm{PLRV}+\mathrm{PVM}+\mathrm{PVS}$ & 2 & 0.6 \\
\hline $\mathrm{PVY}+\mathrm{PLRV}+\mathrm{PVM}+\mathrm{PVA}$ & 2 & 0.6 \\
\hline $\mathrm{PVY}+\mathrm{PVM}+\mathrm{PVX}$ & 2 & 0.6 \\
\hline $\mathrm{PVY}+\mathrm{PVM}$ & 2 & 0.6 \\
\hline $\mathrm{PVX}+\mathrm{PVA}$ & 2 & 0.6 \\
\hline PLRV+PVM + PVS & 2 & 0.6 \\
\hline $\mathrm{PVY}+\mathrm{PLRV}+\mathrm{PVM}+\mathrm{PVS}$ & 2 & 0.6 \\
\hline$P V Y+P V X$ & 1 & 0.3 \\
\hline $\mathrm{PVY}+\mathrm{PLRV}+\mathrm{PVX}+\mathrm{PVM}+\mathrm{PVS}$ & 1 & 0.3 \\
\hline $\mathrm{PVY}+\mathrm{PLRV}+\mathrm{PVX}+\mathrm{PVA}+\mathrm{PVS}$ & 1 & 0.3 \\
\hline $\mathrm{PVX}+\mathrm{PVM}+\mathrm{PVA}+\mathrm{PVS}$ & 1 & 0.3 \\
\hline $\mathrm{PLRV}+\mathrm{PVX}+\mathrm{PVM}+\mathrm{PVA}+\mathrm{PVS}$ & 1 & 0.3 \\
\hline PLRV+PVM + PVA + PVS & 1 & 0.3 \\
\hline PVA + PVS & 1 & 0.3 \\
\hline Total & 354 & 100 \\
\hline
\end{tabular}


Fig. 2 Prevalence in percentages of potato virus $\mathrm{Y}$ (PVY), potato leaf roll virus (PLRV), potato virus $\mathrm{X}$ (PVX), potato virus $\mathrm{M}$ (PVM), potato virus A (PVA) and potato virus $\mathrm{S}$ (PVS) in Meru and Nyandarua counties over 3 consecutive seasons of long rains 2016, short rains 2016 and long rains 2017 (seasons 1, 2 and 3 respectively)

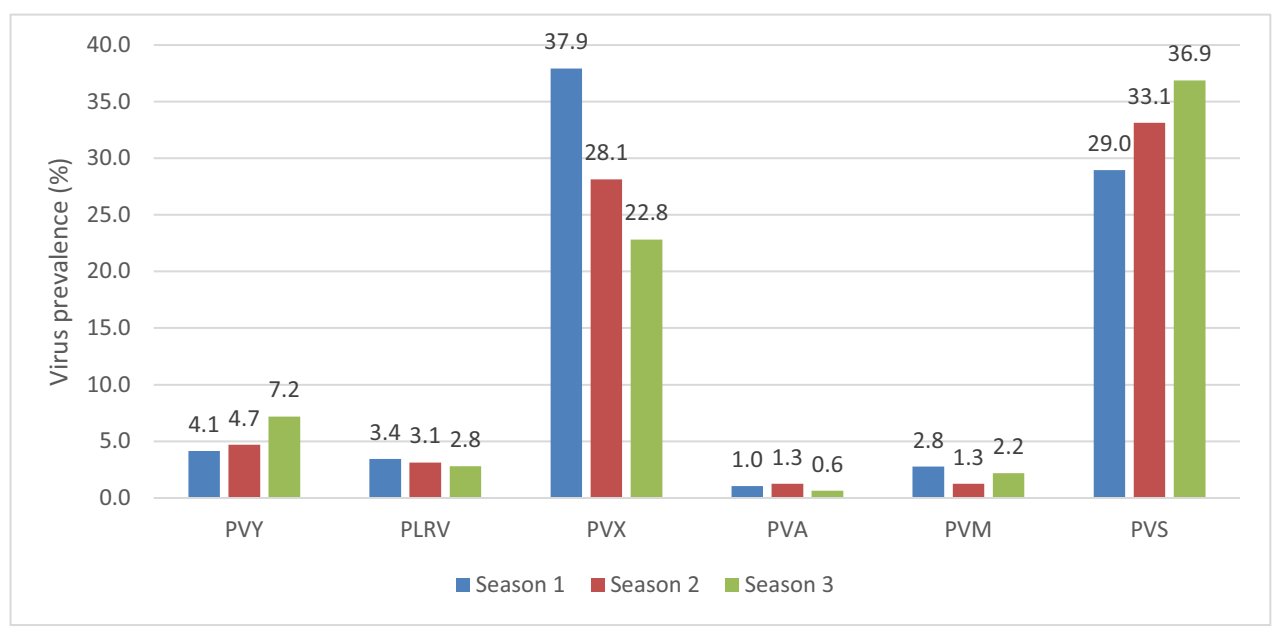

viruses with small variations in prevalence between the seasons and without any clear trend of increase or decrease.

\section{Distribution patterns of six potato viruses in five potato-growing regions}

Figures 3, 4, 5, 6, 7 and 8 show the distribution of the six potato viruses in the five major potato-growing areas as plotted from the geographical coordinates of the sampling sites. PVY, PLRV and PVX were found to be localised only in specific sub-counties within the counties surveyed. PVY (Fig. 3) and PLRV (Fig. 4) were mainly localised to one sub county (Imenti South) in Meru County and in Konoin subcounty in Bomet. PVY was detected in Kiambu and Nyandarua counties but sparsely distributed. PVY was not found in Nakuru County. Apart from being localised in Bomet and Meru counties, PLRV was very sparsely distributed in the rest of the counties.

PVX occurred in almost all counties although it was more densely localised in some particular counties than others and

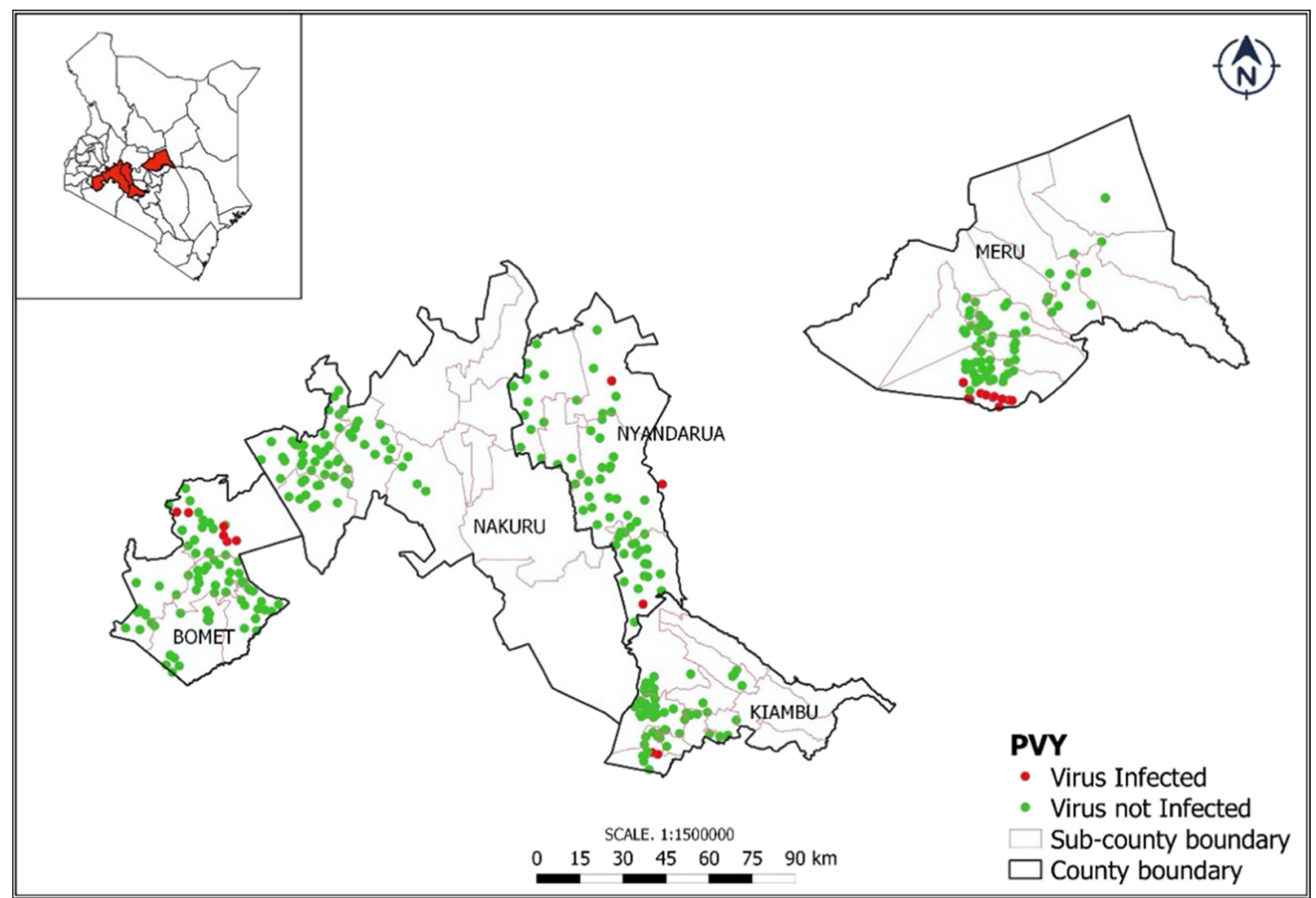

Fig. 3 Map of the distribution pattern of potato virus Y (PVY) in five potato-growing counties in Kenya. Survey points shown in red in the maps represent sites where samples collected were PVY positive while those in green were PVY negative 


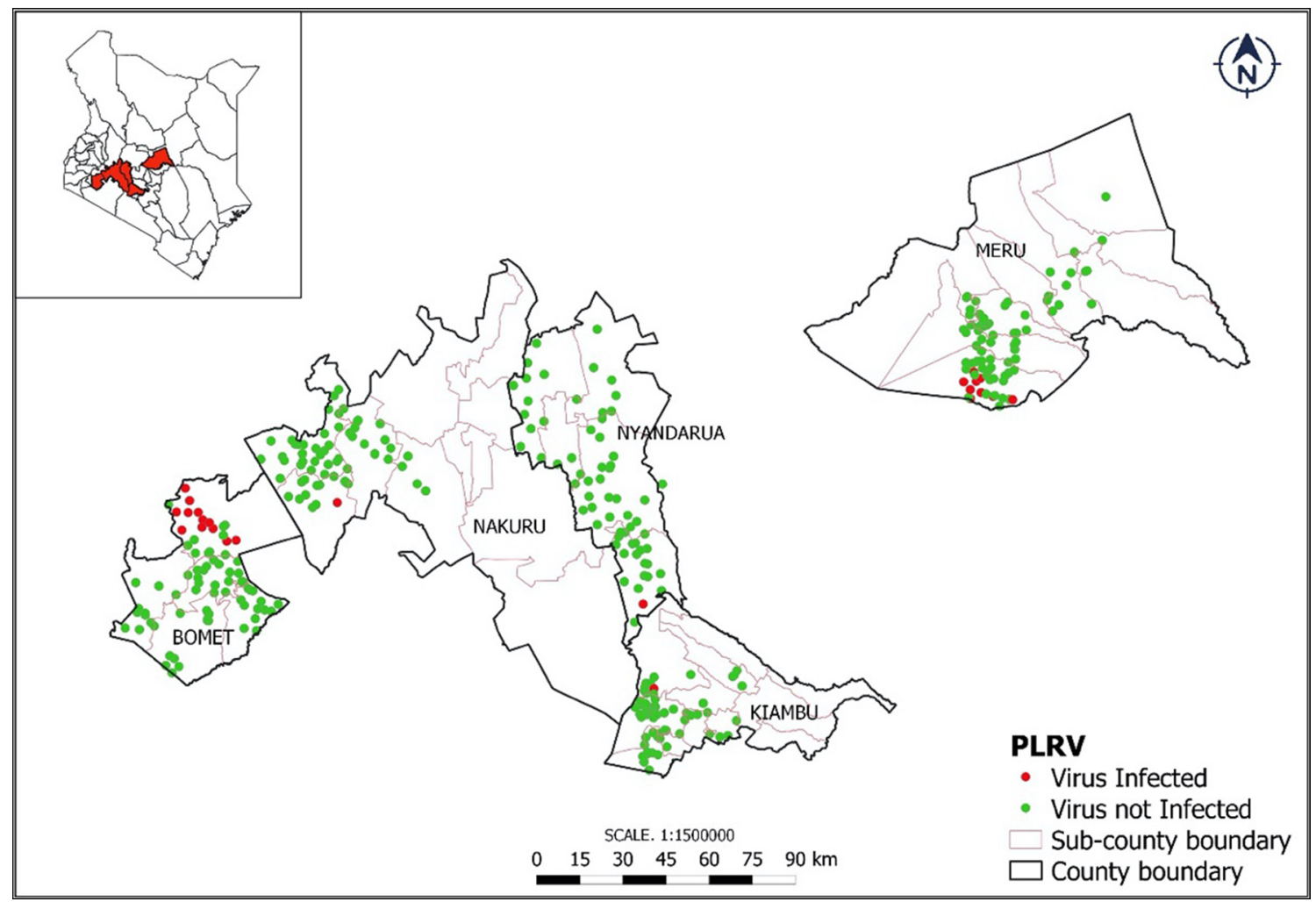

Fig. 4 Map of the distribution pattern of potato leaf roll virus (PLRV) in five potato-growing counties in Kenya. Survey points shown in red in the maps represent sites where samples collected were PLRV positive while those in green were PLRV negative

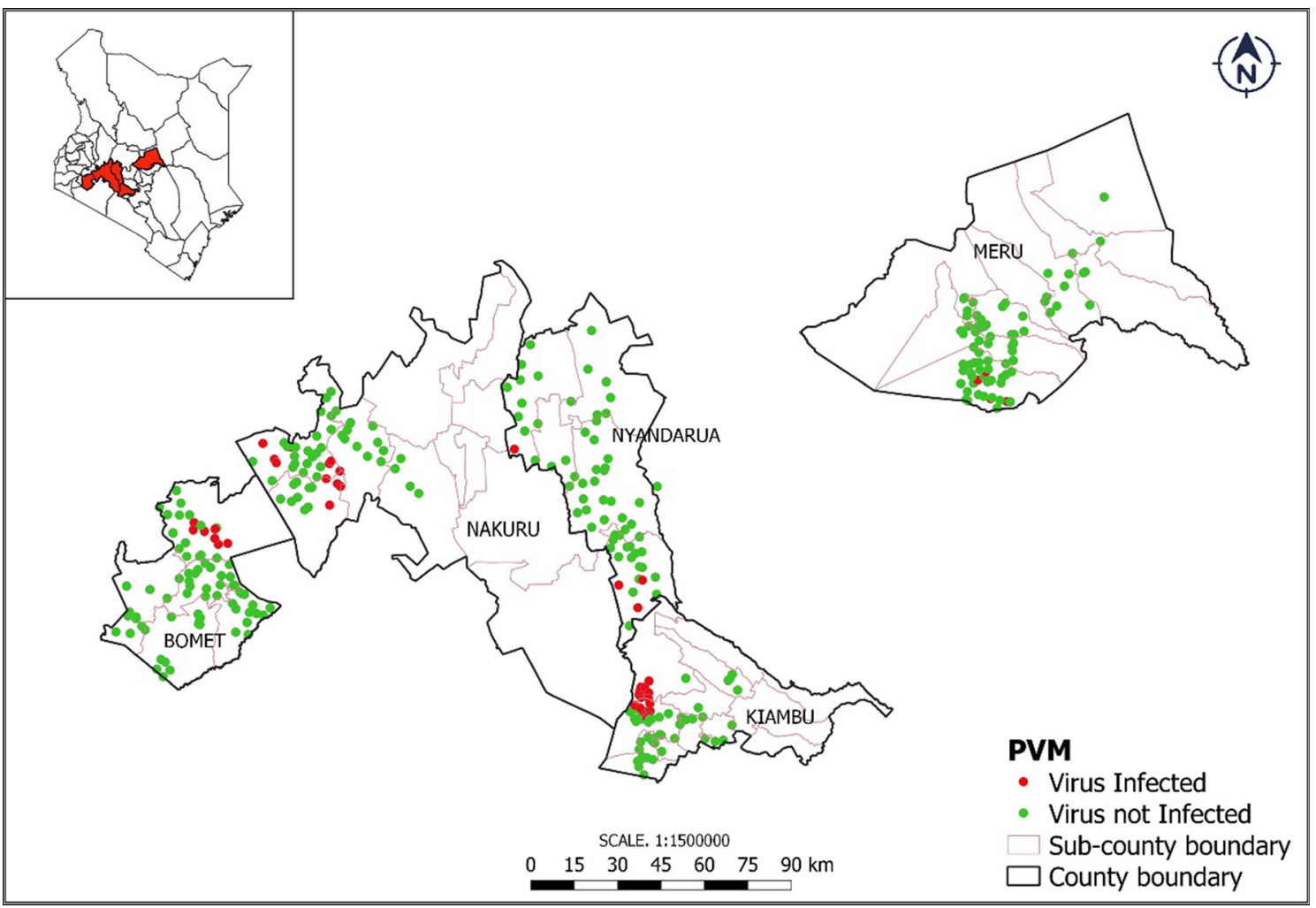

Fig. 5 Map of the distribution pattern of potato virus M (PVM) in five potato-growing counties in Kenya. Survey points shown in red in the maps represent sites where samples collected were PVM positive while those in green were PVM negative 


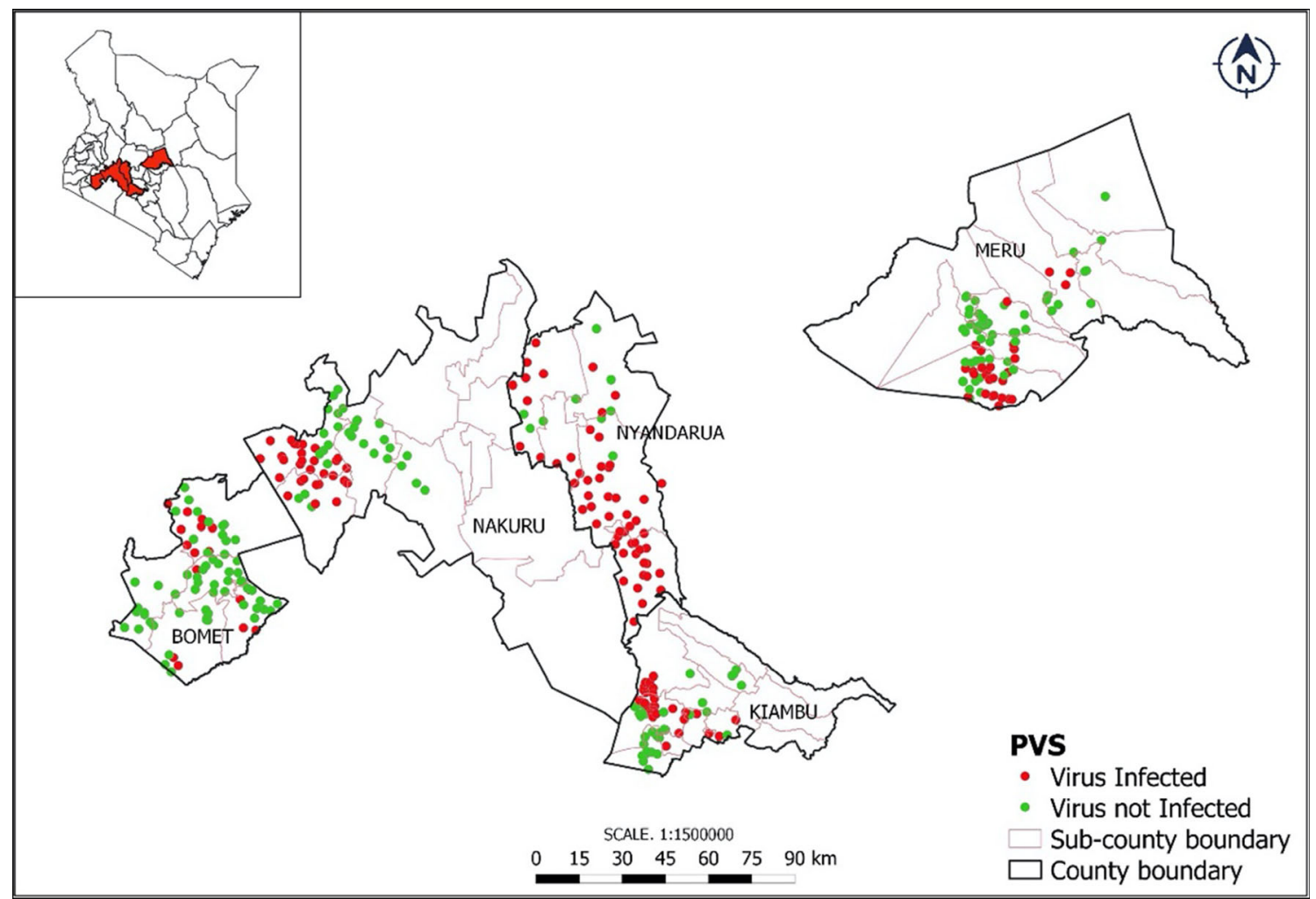

Fig. 6 Map of the distribution pattern of potato virus S (PVS) in five potato-growing counties in Kenya. Survey points shown in red in the maps represent sites where samples collected were PVS positive while those in green were PVS negative

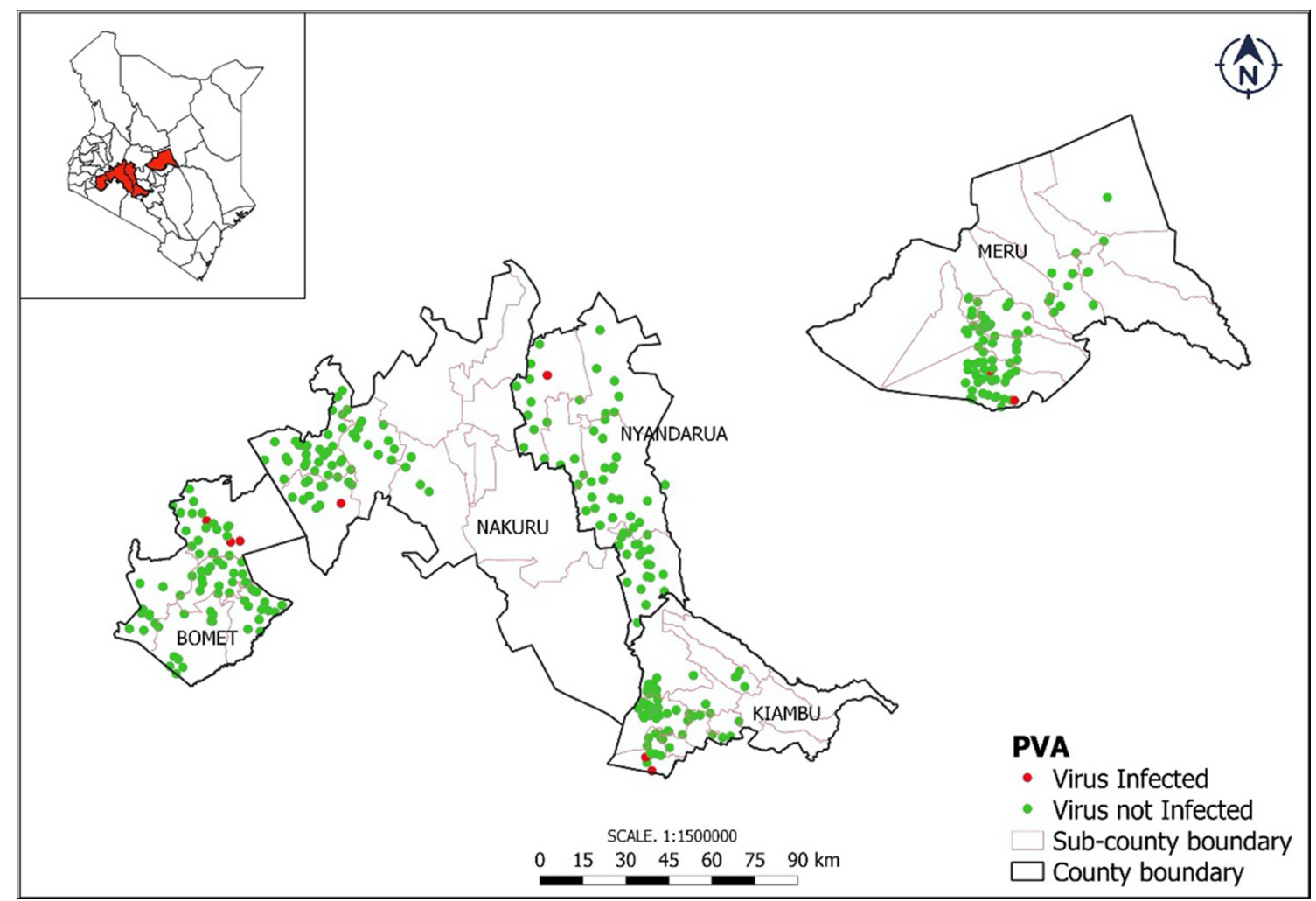

Fig. 7 Maps of the distribution pattern of potato virus A (PVA) in five potato-growing counties in Kenya. Survey points shown in red in the maps represent sites where samples collected were PVA positive while those in green were PVA negative 


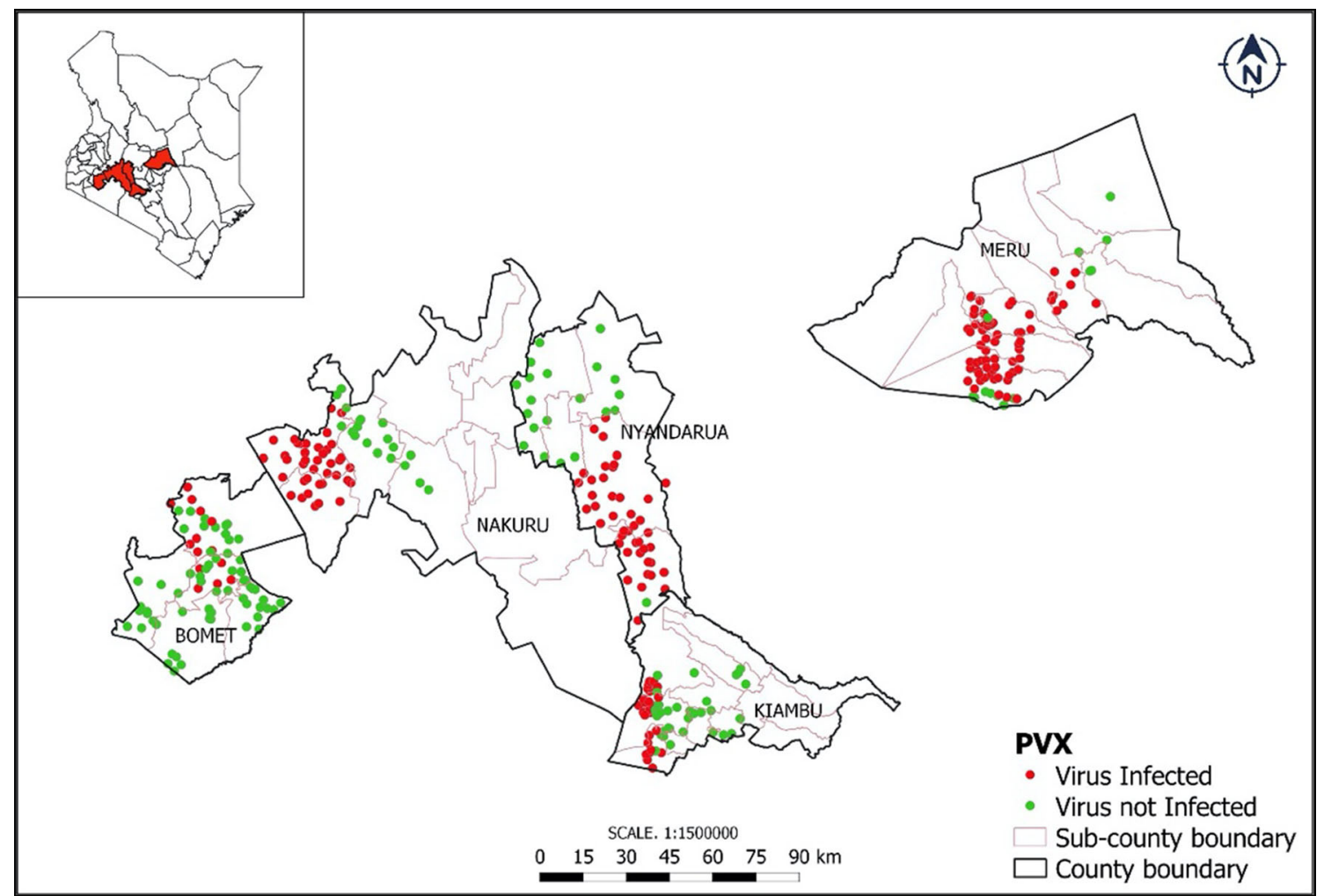

Fig. 8 Maps of the distribution pattern of potato virus X (PVX) in five potato-growing counties in Kenya. Survey points shown in red in the maps represent sites where samples collected were PVX positive while those in green were PVX negative

also within some sub-counties than others (Fig. 8). PVX was densely localised in Molo sub-county in Nakuru County and in Kinangop and Kipipiri sub-counties of Nyandarua County. In Meru County, PVX was found mainly in Imenti south just like in the case of PVY and PLRV. PVX was randomly distributed in Bomet County and in other regions of Meru County. Dense PVX distribution in Kiambu County was skewed towards the western side of the county cutting across different counties. PVM (Fig. 5) was sparsely distributed all over the five counties and even within the sub-counties. It however, occurred densely towards western region of Kiambu County. PVS (Fig. 6) was found to be randomly distributed in all counties and within the sub-counties of the potato-growing regions. PVA (Fig. 7) had similar random distribution across the counties but very more sparsely distributed unlike PVS.

\section{Prevalence of the six potato viruses in different potato cultivars}

Prevalence of the six potato viruses in each of the 13 different potato cultivars grown in five major potato-growing counties in Kenya are summarised in Table 2. The majority of the potato crops in the farmer's fields were mainly from cultivars Shangi $(60.5 \%)$ and Kombere $(15.5 \%)$. The rest of the cultivars were found only in a few farms (each at $<5 \%$ ). Cultivars Sherekea,
Asante, Kenya Karibu, Unica, Thimathuti, Tigoni and Kalucy were not infected with PLRV and PVY. Shangi was found with a low prevalence (1.4\% and $1.9 \%$ respectively) of both viruses. The highest PVY prevalence was found in cultivars Nyayo (66.7\%), Dutch Robyjn (50.0\%) and Nderamwana (50.0\%), Kombere $(27.3 \%)$ and Desiree (14.3\%). The same cultivars (Dutch Robyjn, Nderamwana, Nyayo, Kombere and Desiree) were also found with high PLRV prevalence of $57.1 \%, 50.0 \%$, $33.3 \%, 16.4 \%$ and $14.3 \%$ respectively. PVX infections were found in 11 out of the 13 cultivars with the exception of Thimathuti and Nyayo. All the samples collected from cultivars Tigoni and Kalucy were 100\% infected with PVX. Other cultivars found with high PVX prevalence included Asante (92.9\%) Kombere (85.5\%), Unica (80\%), Sherekea (57.1\%), Nderamwana (50.0\%), Shangi $(45.8 \%)$, Kenya Karibu (40.0\%), Desiree (28.6\%) and Dutch Robyjn (28.6\%).

Sherekea was the only cultivar that was not found with any PVM infection. The rest of 12 cultivars were all infected with PVM with varying prevalences. This virus was detected in $100 \%$ of the samples collected from cultivars Nderamwana, Nyayo, Kalucy and Thimathuti. PVM infections occurred in Dutch Robyjn, Tigoni, Kombere, Unica, Desiree, Kenya Karibu, Asante, Sherekea and Shangi with prevalences of $78.6 \%, 54.5 \%, 7.3 \%, 20 \%, 14.3 \%, 40.0 \%, 14.3$ and $4.2 \%$ respectively. PVS was found in all the cultivars with $100 \%$ infection in cultivars Nderamwana, Kalucy, Nyayo and 
Table 2 Virus prevalence per cultivar in percentages of the 354 samples tested for potato virus $\mathrm{Y}$ (PVY) potato leaf roll virus (PLRV), potato virus X (PVX), potato virus $\mathrm{M}$ (PVM), potato virus $A$ (PVA) and potato virus $S$ (PVS) in 13 potato cultivars grown in Kenya

\begin{tabular}{llcrrrrrr}
\hline Cultivar & No. of samples & \% of samples & PVY & PLRV & PVX & PVM & PVA & PVS \\
\hline Nderamwana & 2 & 0.6 & 50.0 & 50.0 & 50.0 & 100.0 & 0.0 & 100.0 \\
Dutch Robyjn & 14 & 4.0 & 50.0 & 57.1 & 28.6 & 78.6 & 21.4 & 64.3 \\
Kalucy & 2 & 0.6 & 0.0 & 0.0 & 100.0 & 100.0 & 0.0 & 100.0 \\
Nyayo & 3 & 0.8 & 66.7 & 33.3 & 0.0 & 100.0 & 0.0 & 100.0 \\
Tigoni & 11 & 3.1 & 0.0 & 0.0 & 100.0 & 54.5 & 0.0 & 54.5 \\
Thimathuti & 1 & 0.3 & 0.0 & 0.0 & 0.0 & 100.0 & 0.0 & 100.0 \\
Kombere & 55 & 15.5 & 27.3 & 16.4 & 85.5 & 7.3 & 3.6 & 43.6 \\
Unica & 5 & 1.4 & 0.0 & 0.0 & 80.0 & 20.0 & 20.0 & 60.0 \\
Desiree & 7 & 2.0 & 14.3 & 14.3 & 28.6 & 14.3 & 14.3 & 71.4 \\
Kenya Karibu & 10 & 2.8 & 0.0 & 0.0 & 40.0 & 40.0 & 0.0 & 50.0 \\
Asante & 14 & 4.0 & 0.0 & 0.0 & 92.9 & 14.3 & 0.0 & 14.3 \\
Sherekea & 16 & 4.5 & 0.0 & 0.0 & 57.1 & 0.0 & 7.1 & 42.9 \\
Shangi & 214 & 60.5 & 1.4 & 1.9 & 45.8 & 4.2 & 0.5 & 46.7 \\
Total & 354 & 100.0 & & & & & & \\
\hline
\end{tabular}

Thimathuti. PVS prevalence in almost all cultivars was relatively high prevalence of $64.3 \%, 54.5 \%, 43.6 \%, 60.0 \%$, $71.4 \%, 50.0 \%, 14.3 \%, 42.9 \%$ and $46.7 \%$ in Dutch Robyjn, Tigoni, Kombere, Unica, Desiree, Kenya Karibu, Asante, Sherekea and Shangi respectively. Out of the 13 cultivars, PVA occurred in the least number of cultivars (only in four) and at relative lower prevalence with $21.4 \%$ in Dutch Robyjn, $20 \%$ in Unica $14.3 \%$ in Desiree and $3.6 \%$ in Kombere.

\section{ELISA OD values of the six potato viruses in the cultivars}

The average ELISA OD values representing concentrations of each of the six potato viruses in the 13 potato cultivars are presented in Fig. 9. Cultivars with the lowest ELISA OD values considering all the six potato viruses (Fig. 9) were Sherekea, Kenya Karibu, Shangi, Asante and Unica as compared to the rest of the cultivars. Thimathuti, Dutch Robyjn,
Nyayo, Kombere, Desiree, Kalucy and Tigoni had moderate concentrations of the viruses.

The average ELISA OD values in samples found infected were highest in PVS (0.73) followed by PVX (0.57), then PVM (0.42), PLRV (0.16), PVY (0.12) and PVA (0.06) were lowest. The cultivar-virus combination with the highest average ELISA OD value was found in cultivar Kalucy with PVX (1.992). This was followed by Nderamwana with PVS (1.836), Thimathuti with PVM (1.773), Thimathuti with PVS (1.431), Kombere with PVX (1.408), Nyayo with PVS (1.190), Dutch Robyjn with PVS (1.096), Desiree with PVS (1.063) and Nderamwana with PVM (1.016).

\section{Discussion}

In Kenya, the first organised field survey on potato viruses was conducted during the potato-growing seasons of 1996 and
Fig. 9 The average ELISA OD values for potato leaf-roll virus (PLRV), potato virus Y (PVY), potato virus $\mathrm{X}$ (PVX), potato virus (PVM), potato virus S (PVS), potato virus A (PVA) and potato virus S (PVS) in samples collected from 13 potato cultivars grown in five major potato-growing counties in Kenya

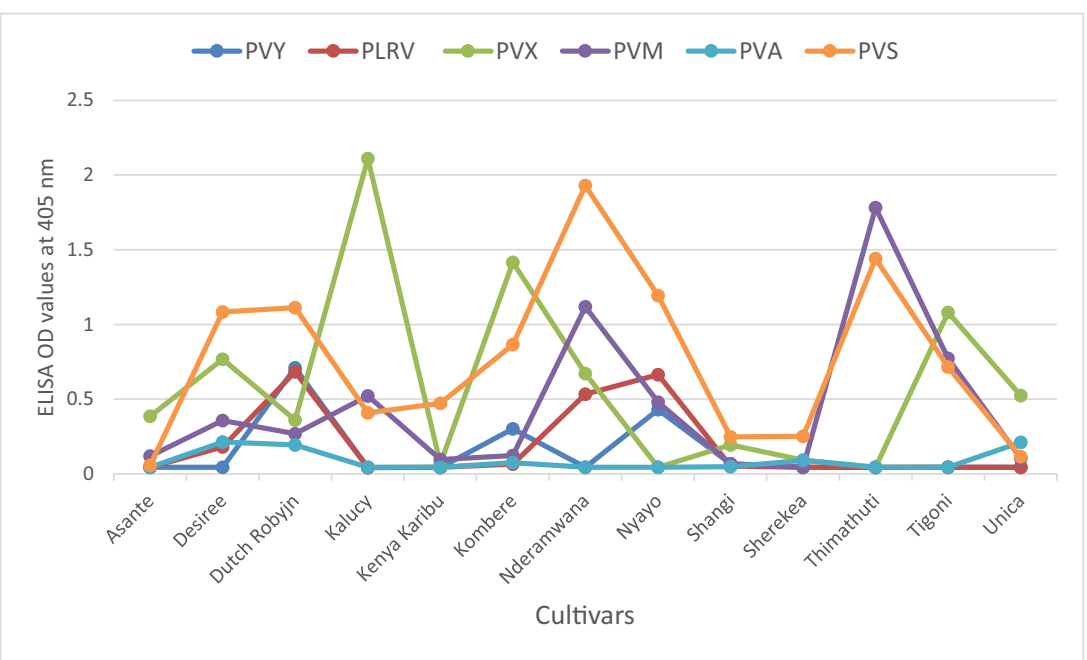


1998 in four regions (Nyamira, Kisii, Meru and Kiambu) on 80 leaf samples which were tested in ELISA only for PLRV. PLRV prevalence was $7.7 \%$ based on ELISA and $8.9 \%$ based on virus symptoms (Were et al. 2003). Almost a decade later (in 2006), another field survey was conducted in Nakuru, Kirinyaga, Nyeri, Laikipia, Meru, Nyeri and Nyandarua regions, but on only for PVY, PLRV, PVX and PVA. In this survey, PVY was the most prevalent virus with $77.6 \%$ followed by PLRV (74.0\%), PVX (57\%) and PVA (42\%) (Gildemacher et al. 2009). Two years later (in 2008), another survey was conducted involving all the six potato viruses (PVY, PLRV, PVX, PVM, PVS and PVA) for the first time. The most prevalent viruses were PVS (99.0\%), PLRV (80.0\%) and PVY (70.0\%). PVX, PVA and PVM were found with a lower prevalence of $45 \%, 40 \%$ and $26 \%$ respectively (Muthomi et al. 2009). A more recent survey was done in 2011 and only one virus (PVY) was tested for in ELISA. Highest PVY prevalence was found in Meru (77.8\%), followed by $73.3 \%$ in Kiambu and $64.0 \%$ in Nyandarua (Nyamwamu et al. 2014).

Organisation and implementation of previous surveys were not the same in terms of the number of samples collected, types of samples (tubers or leaves), number of regions surveyed, method of virus diagnosis (visual or serological), time intervals of conducting the surveys and types of sampling (whether on all plants or on only symptomatic plants). This makes their results difficult to compare and use in making recommendations for virus control. In the absence of an organised and consistent surveillance system, it would be difficult to manage the virus problem (Frost et al. 2013; Yadav and Khurana 2015; Okonya et al. 2019) and this can be a predisposing factor for further virus spread. Therefore, we provided the status in the year 2016 of the six most important potato viruses from the major potato-growing regions and linked the overall virus prevalence figures to actual virus distribution patterns while exploring options for virus control in the agronomically important cultivars in these regions.

We started off by finding out the extent of the potato virus problem in the country. The overall prevalence of the six viruses was high $(72.9 \%$ of the samples were found with at least one of the six viruses) just as reported in past virus prevalence surveys. This implies that there is a need to set up a strategy for virus control. Contrary to the previous surveys which found PVY and PLRV as the two most prevalent viruses, we found PVX and PVS with highest prevalence of $54.8 \%$ and $47.5 \%$ respectively.

We wanted to find out if virus prevalence was changing over the consecutive potato cropping seasons in the regions. To confirm this, we conducted a survey across three consecutive seasons, and we found major changes in virus prevalence. Due to the changing virus prevalence over time, the most recent information about virus prevalence should be considered most reliable for decision making in virus control.
Such changes in virus prevalence may be influenced largely by the changes in cultivars preference (with varying levels of virus resistance). Over the past few decades, there have been major changes in the types of potato cultivars grown by the Kenyan farmers. For instance, Shangi which was grown by only $5 \%$ of farmers in 2008 is now (2016) the main cultivars grown by $60.2 \%$ of the farmers (Crissman 1993; Kaguongo et al. 2008; Onditi 2020).

The viruses were found to occur mainly $(55.9 \%)$ as multiple infections. This has also been reported in the previous virus prevalence surveys in Kenya. Research in other countries has shown that such multiple virus infections can cause a synergistic increase in their pathogenicity resulting to even higher crop losses (Brandolini et al. 1992; Kerlan and Moury 2008). Due to the high prevalence of multiple infections, we recommend breeding for multiple resistance to viruses rather than focusing on only one virus.

Virus distribution in the potato-growing counties were found to occur only in specific geographic localities. For instance, we identified PVY and PLRV to occur primarily in specific sub-counties of Meru and Bomet counties. Differential spread of potato viruses in different potatogrowing localities may be influenced by a variety of factors like the cultivars grown by farmers, availability of healthy potato planting material, vector activity and vector abundance, different cultural farming practices, availability of sources of virus inoculum like potato volunteers and alternative host plants of the viruses (Kreuze et al. 2020). In this study, Bomet County is separated geographically from Nyandaraua and Kiambu counties by The Rift Valley, which passes through most of Nakuru County, a lower altitude area (not suitable for potato cultivation) where potato is not grown over a distance of about 100-200 km. Meru County is on the slopes of Mt. Kenya and is separated from the rest of the counties by about 200-300 km (Figs. 3, 4, 5, 6, 7 and 8). This geographical separation coupled with varying climatic conditions in the different potato-growing regions could be one of the reasons for the variation in prevalence and distribution of the six viruses, though no research has been conducted to confirm this in Kenya. The ethnic group farmers in Bomet County are culturally different from those in Nyandarua, Kiambu and Nakuru and those in Meru, same as their farming practices which may also affect potato virus epidemiology and control. KALRO Centre based at Tigoni, Kiambu County and Agricultural Development Corporation (ADC) based at Molo in Nakuru County and private seed producers have been multiplying and distributing certified potato seed to the farmers (NPCK 2017). Due to lack of data on quantity and the regions where certified potato seed has been distributed in the past, it is difficult to make inferences as how distribution of certified seed may have influenced virus prevalence and distribution in the farmer's fields as shown in this study. Further research therefore needs to be conducted to understand 
reasons for the dynamics of virus prevalence and distribution in Kenya.

The knowledge of variation in virus distribution can help in targeting virus control in those specific regions to cut the cost and logistics of virus control. Training of farmers and dissemination of virus control technologies can therefore be targeted specifically to regions identified with high virus problem. One of the things that can be done in those regions is to advice farmers to avoid growing cultivars identified with high virus prevalence and replace them with those recommended as resistant in this study like Sherekea, Kenya Karibu, Shangi, Asante and Unica. In such regions, farmers can also practice positive selection to improve quality and health of the tubers they plant over seasons (Gildemacher et al. 2009; SchulteGeldermann et al. 2012; Kanguoungo et al. 2014; Onduru et al. 2019; Priegnitz et al. 2019) and subsequently improve potato tuber yields. Because certified seed tubers available to the farmers in Kenya is scarce with only $5 \%$ of the total demand currently produced (NPCK 2017), the little available certified seed tubers can be targeted for distribution to specific regions identified with high virus prevalence. This being the first time the map of the prevalence of the six viruses in the region was constructed, it would be useful to conduct similar surveys in the future to trace and contain virus spread.

Due to observed variations in virus prevalence in cultivars, this study intended to identify virus resistant cultivars from virus prevalence surveys as a faster alternative way of getting information that can be used in virus control. Virus resistance in cultivars was therefore deduced by quantifying the concentration of the viruses in the infected plants using ELISA OD values and from overall virus prevalence in each of the cultivars. There is often higher concentration of viruses and higher prevalence of viruses in susceptible cultivars than in resistant ones as reviewed by Solomon-Blackburn and Barker (2001). We identified four cultivars with fairly low average concentrations of all the six viruses (Fig. 9): Unica, Sherekea, Shangi and Kenya Karibu. Three of these cultivars (Unica, Sherekea and Kenya Karibu) were also found without infection of the two viruses (PVY and PLRV) that causes major yield losses. Just as found in this study, preliminary screening for virus resistance in the three cultivars at CIP, Lima prior to their introduction and release in Kenya indicated that they are resistant both to PLRV and PVY (NPCK 2017). Shangi and Sherekea were recently found not infected with PVY and PLRV after four season's field exposure to the viruses in Kenya (Onduru et al. 2019). Shangi, the main cultivars grown by farmers was found with a very low prevalence of $1.4 \%$ and $1.9 \%$ of the two viruses.

Deductions about the levels of virus resistance in the cultivars from the virus prevalence surveys were based on the following assumptions: (1) The potato crops grown have been exposed to natural sources of virus infections in the field over several seasons. The screening for resistance from virus prevalence surveys in this case was based on the fact that the majority (95\%) of Kenyan famers do not plant certified seed tubers implying that they replant their own saved seed tubers over several seasons (NPCK 2017). This practice exposes the cultivars grown in the field to both aphid and seed tuber transmission of virus (Thomas-Sharma et al. 2016) and also simulates a field exposure trial for screening for virus resistance (Davies et al. 1975). Virus-resistant cultivars under such field exposure trials are normally found without or with very low prevalence of the viruses (Davies et al. 1975; SolomonBlackburn and Barker 2001). From this study, the fact that the cultivars had been exposed to natural sources of virus infection was confirmed by the high virus prevalence observed particularly in virus susceptible cultivars like Kombere, Nyayo, Dutch Robyjn and Nderamwana (Table 2). Cultivars with virus resistance are known to withstand degeneration of crop quality resulting from virus infections in the field (Davies et al. 1975) and can give fairly high yields despite exposure to different sources of virus infections like in the Kenyan situation. Such virus-resistant cultivars can be recommended to reduce virus prevalence among the Kenyan farmers; (2) The number of samples from the different cultivars is statistically representative for the geographical region where the samples were collected. Kenyan farmers were found to grow mainly two cultivars (Shangi $60.2 \%$ and Kombere $15.5 \%$ ) while the rest of the cultivars were grown only in few farms. It is therefore difficult to draw conclusions about possible levels of resistances in the cultivars which were underrepresented; and (3) The results obtained in this study were also confirmed by in a separate controlled virus resistance screening experiment for PVY, conducted both in the greenhouse and in the field (Onditi 2020). Cultivars were inoculated with PVY and grown both in the greenhouse and in the field while replanting harvested tubers over three consecutive seasons (Onditi 2020). The same cultivars were found with the lowest infections of PVY as in this study.

Because all the above assumptions were met for the case of cultivar Shangi, we can conclude that resistance as observed was more cultivar based rather than based on specific virus control measures as possibly implemented by the farmers. However, we cannot be certain about resistance in the rest of cultivars because they were only grown by a few farmers and hence the samples analysed may have not been statistically representative. For this method of screening for virus resistance to work best, larger number of samples need to be collected to ensure that cultivars grown only by few farmers are adequately represented. Future experiments could also consider using sources of antibodies (test kits) that have been validated to be equally specific for the different PVY strains to prevent any bias in resistance assessment.

As a long-term solution to the virus problem, there is need to develop new improved cultivars with traits that respond to the needs of Kenyan farmers with major focus on 
incorporating multiple virus resistances. Successful screening for virus resistance from prevalence surveys in cultivars can provide useful information for virus control within the shortest duration of time and is cheaper as compared to developing new cultivars with virus resistance. It is also easy to implement because the cultivars identified as resistant are already adopted by farmers. Apart from utilising host resistance, there is also a need to improve production of certified seed produced as a way of lowering virus prevalence in farmer's fields. Further research however needs to be conducted to provide further information on other methods of virus control and to identify the reasons for the dynamics in virus prevalence, distribution and relative importance as identified in this study.

Acknowledgements Sincere thanks to Deo-Gratias Hougni of Plant Production Systems, (WUR) for advice on data analysis and Kevin Waweru from the University of Nairobi for helping me in sample collection and serological assays. I also thank the Kenyan famers and the staff from the Ministry of Agriculture Livestock and Fisheries for their guidance during sample collection.

Authors' contribution This work was conceptualised and discussed by all the three co-authors prior to implementation. The actual research work (experimental design, sample and data collection in the field, laboratory tests and data analysis and presentation) were done by the first author (John Onditi). Supervision and provision of equipment's and facilities for conducting the experiments were done equally by the other two authors. The corresponding author (Rene van der Vlugt) played the overall supervisory role in the project. The first draft of this manuscript was prepared by John Onditi. This was improved twice with equal contribution of all the authors before submission.

Funding This study is financially supported by Wageningen University and Research (WUR) and Kenya Agricultural and Livestock Research Organization as part of a collaborative $\mathrm{PhD}$ research project at WUR and KALRO.

Data availability The datasets generated during and/or analysed during the current study are available from the corresponding author on reasonable request.

\section{Compliance with ethical standards}

Conflict of interest The authors declare that they have no conflict of interest.

Open Access This article is licensed under a Creative Commons Attribution 4.0 International License, which permits use, sharing, adaptation, distribution and reproduction in any medium or format, as long as you give appropriate credit to the original author(s) and the source, provide a link to the Creative Commons licence, and indicate if changes were made. The images or other third party material in this article are included in the article's Creative Commons licence, unless indicated otherwise in a credit line to the material. If material is not included in the article's Creative Commons licence and your intended use is not permitted by statutory regulation or exceeds the permitted use, you will need to obtain permission directly from the copyright holder. To view a copy of this licence, visit http://creativecommons.org/licenses/by/4.0/.

\section{References}

Beukema HP, van der Zaag DE (1990) Introduction to potato production. PUDOC, Wageningen, Netherlands

Birch PRJ, Bryan G, Fenton B, Gilroy EM, Hein I, Jones JT, Prashar A, Taylor MA, Torrance L, Toth IK (2012) Crops that feed the world 8: potato: are the trends of increased global production sustainable? Food Security 4:477-508

Brandolini A, Caligari PDS, Mendoza HA (1992) Combining resistance to potato leaf roll virus (PLRV) with immunity to potato viruses $\mathrm{X}$ and Y (PVX and PVY). Euphytica 61:37-42

Clark MF, Adams AW (1977) Characteristics of the microplate method of enzyme-linked immunosorbent assay (ELISA) for detection of plant viruses. Journal of General Virology 34:475-483

Crissman CC, Crissman LM, Carli C (1993) Seed potato systems in Kenya: a case study. International Potato Centre, Lima

Davies HT, McEwen HL, Dixon NC (1975) Field testing potatoes for resistance to leaf roll and virus Y. American Journal of Potato Research 52:151-155

FAOSTAT (2017) FAOSTAT. Commodities by country, Kenya, potatoes, 2017. http://www.fao.org/faostat/en/\#rankings/commodities by_country. Accesed in August 20, 2019

Frost KE, Groves RL, Charkowski AO (2013) Integrated control of potato pathogens through seed potato certification and provision of clean seed potatoes. Plant Disease 97:1268-1280

Gildemacher P, Demo P, Barker I, Kaguongo W, Woldegiorgis G, Wagoire W, Wakahiu M, Leeuwis C, Struik PC (2009) A description of seed potato systems in Kenya, Uganda and Ethiopia. American Journal of Potato Research 86:373-382

Gildemacher P, Schulte-Geldermann E, Borus D, Demo P, Kinyae P, Mundia P, Struik PC (2011) Seed potato quality improvement through positive selection by smallholder farmers in Kenya. Potato Research 54:253-266

Jayashige U, Chuquilllanqui C, Salazar LF (1989) Modified expression of virus resistance in potato in mixed virus infections. American Journal of Potato Research 66:137-144

Kaguongo WP, Gildemacher P, Demo P, Wagoire W, Kinyae P, Andrade J, Forbes G, Fuglie K, Thiele G (2008) Farmer practices and adoption of improved potato varieties in Kenya and Uganda. International Potato Centre (CIP), Lima

Kaguongo W, Maingi G, Barker I, Nganga N, Guenthner J (2014) The value of seed potatoes from four systems in Kenya. Am J Potato Res 91(1):109-118

Kerlan C, Moury B (2008) Potato virus Y. In: Mahy BWJ, Van Regenmortel MHV (eds) Encyclopedia of virology, vol 4, 3rd edn. Elsevier, Oxford, pp 287-296

Kim J, Kwon M (2019) Population dynamics of aphid species in Korean seed potato cultivation area over four decades. Entomological Research 49:179-184

Kreuze JF, Souza-Dias JAC, Jeevalatha A, Figueira AR, Valkonen JPT, Jones RAC (2020) Viral diseases in potato. In: Campos H, Ortiz O (eds) The potato crop. Springer, Cham

MoALF (2016) The national potato strategy 2016-2020. Ministry of Agriculture Livestock and Fisheries Nairobi, Kenya

Muthomi JW, Nyaga JN, Olubayo FM, Nderitu JH, Kabira JN, Kiretai SM, Aura JA, Wakahiu M (2009) Incidence of aphid transmitted viruses in farmer-based seed potato production in Kenya. Asian Journal of Plant Sciences 8:166-171

NPCK (2017) Potato variety catalogue. National Potato Council of Kenya. Nairobi, Kenya 
Nyamwamu P, Mukoye B, Osogo A, Omuse C, Ajanga S, Were HK (2014) Distribution and biological characterization of potato virus $\mathrm{Y}$ in Kenya. Journal of Agri-Food and Applied Sciences 2:258-264

Okonya JS, Ocimati W, Nduwayezu A, Kantungeko D, Niko N, Blomme G, Legg JP, Kroschel J (2019) Farmer reported pest and disease impacts on root, tuber, and banana crops and livelihoods in Rwanda and Burundi. Sustainability 11:1592

Olubayo F, Kibaru J, Nderitu J, Njeru R, Kasina M (2010) Management of aphids and their vectored diseases on seed potatoes in Kenya using synthetic insecticides, mineral oil and plant extract. Journal of Innovation and Development Strategy 4:1-5

Onditi J (2020) Epidemiology and control of potato virus Y in Kenya. $\mathrm{PhD}$ thesis, Wageningen University, Netherlands. ISBN: 978-94 6395-322-1

Onditi J, Njoroge K, Shibairo S (2013) Improving potato tuber yields using genotypes with multiple virus resistance in Kenya. Agriculture and Biology Journal of North America 4:406-441

Onduru OG, Narla RD, Otieno HMO, Schulte-Geldermann E (2019) Response of selected potato genotypes to natural virus infection in the field. Asian Journal of Research in Crop Science 3:1-13

Priegnitz U, Lommen WJM, van der Vlugt RAA, Struik PC (2019) Impact of positive selection on incidence of different viruses during multiple generations of potato seed tubers in Uganda. Potato Research 62:1-30

QGIS (2019) QGIS, A Free and Open Source Geographic Information System. https://qgis.org/en/site/. Accessed January 03, 2019

Schulte-Geldermann E, Gildemacher PR, Struik PC (2012) Improving seed health and seed performance by positive selection in three Kenyan potato varieties. American Journal of Potato Research 89: 424-429

Scott GJ, Labarta R, Suarez V (2013) Booms, busts, and emerging markets for potatoes in East and Central Africa 1961-2010. Potato Research 56:205-236

Smith EA, DiTommaso A, Fuchs M, Shelton AM, Nault BA (2012) Abundance of weed hosts as potential sources of onion and potato viruses in Western New York. Crop Protection 37:91-96

Soliman T, Mourits MCM, Oude Lansink AGJM, van der Werf W (2012) Quantitative economic impact assessment of an invasive plant disease under uncertainty. A case study for potato spindle tuber viroid (PSTVd) invasion into the European Union. Crop Protection 40:28-35

Solomon-Blackburn RM, Barker H (2001) A review of host major-gene resistance to potato viruses $\mathrm{X}, \mathrm{Y}, \mathrm{A}$ and $\mathrm{V}$ in potato, genes, genetics and mapped locations. Heredity 86:8-16

Taliansky M, Mayo MA, Barker H (2003) Potato leafroll virus: a classic pathogen shows some new tricks. Molecular Plant Pathology 4:8189

Tesfaye T, Feyissa T, Abraham A (2011) Survey and serological detection of sweet potato (Ipomoea batatas $(L$. ) Lam.) viruses in Ethiopia. Journal of Applied Biological Sciences 41:2746-2756

Thomas-Sharma S, Abdurahman A, Ali S, Andrade-Piedra JL, Bao S, Charkowski AO (2016) Seed tuber degeneration in potato: the need for a new research and development paradigm to mitigate the problem in developing countries. Plant Pathology 65:3-16

Wang B, Maa Y, Zhang Z, Wu Z, Wu Y, Wang Q, Li M (2011) Potato viruses in China. Crop Protection 30:1117-1123

Were HK, Narla RD, Nderitu JH, Weidemann H-L (2003) The status of potato leafroll virus in Kenya. Journal of Plant Pathology 85:153156

Were HK, Kabira JN, Kinyua ZM, Olubayo FM, Karinga JK, Aura J, Lees AK, Cowan GH, Torrance L (2013) Occurrence and distribution of potato pests and diseases in Kenya. Potato Research 123:1225

Whitfield AE, Falk BW, Rotenberg D (2015) Insect vector-mediated transmission of plant viruses. Virology 48:278-289

Whitworth J, Davidson RD (2008). Quality seed: seed improvement, cultivar and seed lot election and certification. pp. 31-41 In: Potato Health Management. D. A. Johnson, ed. American Phytopathological Society, St. Paul, MN

Yadav N, Khurana SMP (2015) Plant virus detection and diagnosis: progress and challenges. Frontier Discoveries and Innovations in Interdisciplinary Microbiology 27:97-132

Publisher's note Springer Nature remains neutral with regard to jurisdictional claims in published maps and institutional affiliations. 